\title{
Uganda's Trade and Revenue Effects with the EAC Countries, DRC and Sudan
}

\author{
Gaalya Micah Samuel \\ Research and Planning Division-Commissioner General's Office, Uganda Revenue Authority, Kampala, Uganda \\ Email:mgaalya@gmail.com
}

Received 22 February 2015; accepted 9 March 2015; published 12 March 2015

Copyright (C 2015 by author and Scientific Research Publishing Inc.

This work is licensed under the Creative Commons Attribution International License (CC BY). http://creativecommons.org/licenses/by/4.0/

(c) (i) 0pen Access

\begin{abstract}
A WITS partial equilibrium model is used to perform simulations on Uganda's trade and revenue effects with the EAC countries, DRC and Sudan using highly disaggregated HSC six-digit level trade data. At the zero percent tariff rate, tariff revenue effects in all country cases were small. At the 25 percent tariff rate, tariff revenue effects in all country cases simulated were large. This indicates that the revenue implications of changes of applied rates depend on the applied tariff rate on imports. High tariff rates show larger revenue effects, while low tariff rates show lower revenue effects. However higher tariff rates show lower trade volumes and lower tariff rates high trade volumes.
\end{abstract}

\section{Keywords}

Tariff Rate, Trade Effects, Revenue Effects, EAC Countries, DRC and Sudan

\section{Introduction}

Trade and tariff revenue effects are an important area of study for low incomes countries liberalizing their trade regimes. In regard to Uganda, the EAC customs union 2006 to 2010 stands out as a major trade liberalization period. The EAC Customs Union eliminated intra-regional tariff and adopted a Common External Tariff (CET) for EAC member states. This raises a lot of questions given that the partner countries are at different levels of economic development and considerably rely on customs tariffs for trade and tax revenue. Uganda's elimination of intra-regional tariff would have its economic performance harmed with respect to trade and tariff revenue, [1].

According to [2], trade and tariff revenue are likely to decrease as a result of the EAC tariff liberalization. There are also expressed fears about Uganda being at a disadvantage compared to its more industrialized neighbors, more specifically Kenya. Based on these concerns, previous studies by [3]-[6] have all investigated trade 
and revenue effects under the EAC framework. The studies do not evaluate Uganda's alternative trade liberalization scenarios with the DRC and Sudan, yet the DRC and Sudan are both Uganda's key trade partners. The shortcomings of these studies create a research gap that calls for more studies on Uganda's probable trade and revenue effects stemming from trade liberalization.

This study therefore contributes to the debate on trade creation, trade diversion and revenue effects in trade literature by undertaking a quantitative study that investigates these effects for Uganda. This study presents empirical analysis of trade effect and revenue effects for Uganda under alternative tariff liberalization scenarios. The alternative policy scenarios can be broadly seen as encompassing regional tariff liberalization options under the EAC framework. The valuations provide insights into questions such as what are the advantages of Uganda entering an Economic Partnership Agreement (EPA) with DRC Congo and Sudan, which are Uganda's key trading partners. What are the potential gains of further and more comprehensive regional liberalization with these countries? This study uses a partial equilibrium model to analyze the alternative tariff liberalization options using highly disaggregated harmonized commodity coding system (HS) six-digit level trade data.

\section{Literature Review}

\subsection{Theoretical Literature on Trade and Revenue Effects}

Theoretical work on trade and revenue effects was introduced by [7] he focused on estimating trade liberalization effects resulting from trade agreements. Viner suggests concepts of trade creation and trade diversion as measurement of trade effects resulting from liberalization. Viner's important contribution to the theory of customs unions and other forms of liberalization was his observation that indefinite welfare effects could be expected from economic integration. The concepts of trade creation and trade diversion are the major building blocks for the quantification of welfare effects that are likely to influence trade liberalization outcomes. Viner in his study about a customs union notes that "If a customs union is a movement in the direction of free trade, it must be predominantly a movement in the direction of goods being supplied from lower money-cost sources to high money-cost sources. If the customs union has the effect of diverting purchases to higher money-cost sources, it is then a device for making tariff protection more effective." Viner uses this explanation to define trade creation as the change in consumption from more costly domestic products to less costly products from a partner country and trade diversion is defined as the change in consumption from less costly non partner country to more costly products from a partner country.

Viner's framework and subsequent theoretical modifications of the framework have provided a methodology for the analysis of both trade and welfare effects. The outcome from formation of a customs union is empirically evaluated by estimating the net effect of trade creation and trade diversion effects. In the analysis, if trade creation exceeds trade diversion then a customs union is considered to be advantageous and welfare enhancing. On the other hand if trade diversion exceeds trade creation then a customs union is considered to be disadvantageous and welfare decreasing. Viner's theoretical framework uses comparative static analysis that is based on a series of restrictive assumptions. The restrictive assumptions facilitate in the estimation of resource allocation, welfare changes and the trends in trade flows. The assumptions are drawn from works of [8] and [9] these include: 1) Perfectly elastic supply for imports; 2) Perfect competition for factor and product markets; 3) Factor mobility within countries but not among countries; 4) Zero transportation costs; 5) Tariffs as the only available policy tool; 6) Prices accurately reflect opportunity costs; 7) Balanced trade; 8) Full employment of resources.

The challenge to Viner original theoretical framework is his inability to estimate economies of scale, imperfect competition and terms of trade issues. The three issues were left unattended to, despite having been recognised by Viner. The studies that have preceded Viner's work have dealt with the challenges pointed out by Viner, in addition to covering other topics of trade liberalization. For example [8] was credited with having provided the first theoretical analysis of customs unions and trade liberalization using a general equilibrium model. Meade included a critique and extension of Viner's model, which he interpreted as one with infinite supply elasticities and demand elasticities of zero. The major contribution of Meade work was his focus on world welfare and the likely changes that could occur upon the formation of preferential trading arrangements. Meade's work provided a general static framework for analysis of trade agreements. He admitted substitution of demand and supply of goods that allows for simultaneous adjustments in related factor and goods markets in trading countries. He also admitted likely terms of trade effects on the welfare of trading countries and the rest of the world. By allowing for simultaneous adjustments in related factor and goods markets the model has better forecasting 
powers than Viner's models. Other studies that have modified Viner's work are studies by [10] [11] he refined the concepts of trade creation and trade diversion by suggesting the inclusion of consumption effects to invalidate Viner's characterization of assigning a positive connotation to trade creation and a negative implication to trade diversion. He argued that it is possible to increase welfare despite having trade diversion. The insights provided by Viner and others on the formation of customs unions led to questioning the rationale for their foundation given Lipsey's arguments. Lipsey's findings led to the connotation of a second-best option, the second best option was represented by positive welfare effects arising from trade diversion. In this perspective, [12] suggested that customs unions were formed in response to political rather than economic motivations. Johnson advocated that the measurement of trade creation and trade diversion should include production and consumption effects as changes in import demands were a consequence of the formation of a customs union and tariff liberalization. By arguing that it is possible to increase welfare despite having trade diversion, led to the connotation of a second-best option which led to the improvements in estimation of welfare effects.

Another study that modified Viner's work is a study by [13] they argued that welfare effects arising from a customs union had to take into account a tariff reduction component and a pure trade diversion component. The rationale was that a tariff reduction component directly affected consumer surplus, meaning that if a tariff reduction was larger than the pure trade diversion component, then the formation of a customs union would be beneficial and the reverse was true. It was clear to Cooper and Massell that second-best policies had an inherent bias toward protection. These arguments were extended to the case of developing countries where [12] attempted to understand and to consider how membership to a customs union could enable a less developed country to achieve more economically while served by protection. The results showed that the second-best policies had an inherent bias toward protection, which provided an opportunity for the estimation of tariff reduction effects.

Ref [14] and [15] extended the work by recognized investigation and discussion into changes in terms of trade and economies of scale trade and economies of scale effects arising from trade liberalization. [16] recognized the void in literature regarding the issue of terms of trade and how these were likely to impact gains or losses for countries forming a customs unions. Mundell work focused on addressing the tariff liberalization changes on relative prices in a three-country model and their likely effects on the terms of trade. He established that tariff liberalization was likely to affects terms of trade in the model. Ref [15] analyzed whether, in the presence of economies of scale, the concepts of trade diversion and creation were still valid. Corden suggested that the consideration of terms of trade and economies of scale was necessary and demonstrated the existence of cost reduction and trade dominance effects related to scale economies. Corden found that terms of trade and economies of scale effect were more important than trade creation and trade diversion effects. He therefore argued that terms of trade and economies of scale effect have to be taken into consideration in estimating trade liberalization effects. Despite the significance of terms of trade effects and economies of scale proposed by both Mundell and Corden, trade creation and trade diversion remain relevant in the estimation of trade liberalization effects.

The literature initiated by Viner and substantially enriched by [11]-[15] among others addressed the basic effects of trade liberations. The studies predicted that the idea of formation of a customs union as a form of trade liberalization, could lead to both gains and losses in world welfare. These ideas are valid in the theory of trade liberalization, the notion and the likelihood that the results could also depend on other economic factors gave ample space for theoretical discussion and for empirical investigation.

In summary trade liberations can be fully estimated by trade creation and trade diversion effects as proposed by [13] and [7] who proposed that trade liberalization effects from tariff reduction can be estimated by terms of trade effects. While [14] and [15] proposed that trade liberalization effects can be estimated by trade effects and economies of scale. In general trade liberalization effects can be theoretically sub-modelled within these major areas of trade creation, trade diversion, trade effects and economies of scale.

\subsection{Methods for the Analysis of Trade and Revenue Effects}

There are mainly three methods commonly used in empirical studies of trade agreements and trade liberalization these include econometrics models, computable general equilibrium (CGE) models and partial equilibrium (PE) models. The methodologies are employed depending on the study to be under taken either ex-ante or ex-post. The ex-ante analysis simulates the likely outcomes of the probable post-liberalization scenarios. While ex-post analysis is performed after implementation of trade liberalization and use historical data to ascertain the outcomes of liberalization. The objective of ex-ante and ex-post analysis is to estimate trade flows of a hypothetical 
condition, termed as the anti-monde, based on the absence of a trade agreement and compare them to conditions prevalent after trade liberalization. The three methodologies are discussed below.

\subsubsection{Econometrics Models}

Econometrics models particularly gravity models were introduced by [17] these have been used in the empirical analysis of international trade effects. Economists have used econometrics models to analyse a host of trade issues such as economic unions, free trade agreements and relationship between trade and growth. The major econometric models used are gravity models. The gravity model has in most of its empirical applications, performed well and demonstrated its usefulness as a method of analysis.

Gravity models have proven effective in predicting trade flows and have exhibited good explanatory power. The model has also proven to be easy to work with, as it is clear, simple and intuitive. In addition, data requirements are fairly limited and these data are usually available. However, some features of gravity models have raised questions about its validity as a methodology. The primary critique levelled has been that they lack a theoretical foundation based on traditional international trade theory [18]. The gravity model contradicts Ricardian model, which explains trade flows on the basis of technological differences, as well as Heckscher-Olin model which bases its explanation on factor endowments [19]. In addition estimation and econometric issues have also prompted criticism of the gravity model. The proper specification of the gravity equation has been a subject of considerable debate and model has been considered mis-specified. Ref [19] has summarized some weaknesses inherent in the gravity model. First, the high explanatory value yielded by the gravity model may tempt some to add explanatory variables in a rather arbitrary fashion without strong theoretical support for such inclusion. Just as the omission of an important determinant of trade can lead to bias, inclusion of irrelevant variables can lead to misspecification. Second, studies often fail to consider relative trade costs and distance while considering only their absolute values. Third, problems arise in the study of bilateral trade when countries do not trade with each other and the observations include a zero. This can lead to biased and inconsistent estimates if these observations are omitted. On this point, [18] noted that alternative techniques in non-linear estimation allow for including zero observations hence, these make use of valuable information contained in such observations. Fourth, endogeneity bias arises as institutional quality, country infrastructure and other issues affect GDP and GDP per capita. In General these criticisms need to be addressed before adopting the gravity model. Over the years gravity models have been modified to allow for the estimation of trade diversion and trade creation and in assessing trade effects in economic integration agreements [20].

\subsubsection{Computable General Equilibrium Models (CGE)}

Computable General Equilibrium (CGE) models are constructed on the basis of general equilibrium theory and offer a framework of analysis that is rigorous as well as theoretically consistent. The models consider the workings of an economy and the changes that would follow specific policy implementation to perform simulations. CGEs models have played a significant role in ex-ante modelling of international trade Piermartini and the, (2005). CGE simulations can be used to evaluate trade policy alternatives. The alternatives involve modelling trade and welfare effects of economic integration agreements. The CGE model presents the overall aggregate trade, terms of trade effects, factor prices, trade creation and trade diversion within an economy-wide model.

The CGE model builds inter-sectoral linkages, estimates of prices, wages, and exchange rates that lead to equilibrium in product and factor markets and the balance of trade figures. The estimates for prices, wages and exchange rates as well as the balance of trade are considered in the estimation of parameters for the model. The analysis is based on the differences in values in the pre and post-implementation situations, this allows for the evaluation of alternative scenarios. The scenarios relate to the identified gains, losses and distributional effects from policy actions [18].

Although highly detailed and sophisticated, CGE models have some limitations and they have equally drawn some criticism. Taking a general equilibrium approach and considering that they are an economy wide model, CGE models have an inherent burdensome data requirement problem. CGE models require a full account of trade flows, tariff rates, macroeconomic data as well as a wealth of additional government data on various variables. Data is often missing or inconsistent thus posing some difficulties. Based on this burdensome and problematic data requirement, researchers are moving toward the use of alternative methodologies [18] and [19]. Another criticism levelled against CGE models is the use of highly aggregation data, the aggregation comes at the expense of concealing greater detail. The aggregation is bound to conceal some fundamental relationships in 
the data matrices.

In addition, when dealing with preferential trading arrangements analysts must take into account that CGE models, by virtue of generally being static, cannot adequately adjust when different phases of RTAs enter into effect [18]. CGE models are also often questioned for drawing values for critical behavioural parameters from out dated econometric work. It is usually the case that the Armington, substitution and other elasticities and parameter values are chosen arbitrarily. From CGE assessment, some studies have suggested that systematic validation of CGE simulations through ex-post evaluation is necessary to enhance the confidence and the predictive potential of the analytical results [19].

\subsubsection{Partial Equilibrium Models}

The static partial equilibrium ex-ante and ex-post models are used to predict or simulate the effects of trade policy changes when tariff rates are expected to be modified, as is the case in the formation of trade agreements or other trade liberalization schemes. The partial equilibrium models have been used in discriminatory trade analysis following the pioneering work by [21] and [7]. The partial equilibrium models are derived from Viner's trade creation and trade diversion theoretical formulation. The key feature of the partial equilibrium models is its ability to estimate trade creation and trade diversion. Verdoorn developed this methodology in order to quantify the effects of the formation of a customs union amongst European countries. Verdoorn model was developed during the formation stages of the European Economic Community. Verdoorn used his model to quantify the trade effects of the Benelux customs union at the time. However subsequent studies have modified the partial equilibrium model developed by Verdoorn's to estimate trade creation and trade diversion effects arising from a customs union. The partial equilibrium models suffers from similar criticism as the CGE model, however the partial equilibrium model doesn't suffer from burdensome data requirement problem and remains easier to construct and use as compared to the CGE model. Generally, the methods for the analysis of trade agreements and trade liberalization have shown that econometric models particularly gravity models, computable equilibrium models, and partial equilibrium models are used to estimate trade and revenue effects. The partial equilibrium model is the preferred methodology for this chapter and a detailed a review of empirical studies is presented below.

\subsection{Empirical Literature}

Ref [22] addressed the issue of trade preferences by reviewing some prior studies and questioning why different studies have considerably different quantitative results. The study by MacPhee and Oguledo used a variant of the Verdoorn-Clague partial equilibrium model to estimate ex-post rather than ex-ante trade benefits granted by the GSP scheme in the US. They employed the changes from market growth and improved competitiveness and subtracted them from total growth. Results suggested that imports from beneficiary countries grew faster than from non-beneficiaries, hence implying trade creation outweighing trade diversion. Studying the US and Canadian free trade agreement, [22] employed a partial equilibrium framework to study trade effects. They drew quarterly trade data from 1970-1987 and the estimates were performed at commodity or industry level. The results indicated that significant increases in trade volumes would be present for Canada and the US.

Other studies by [2] [23] and [24] used the Verdoorn model to evaluate trade effects in the formation of alternative trading arrangements. Ref [24] addressed the possible effects of a free trade agreement between Mexico and the EU. They estimated trade effects using 3 digit-level SITC trade data. The results indicated that total trade effects were positive with EU gains much larger than those of Mexico.

Among the studies conducted on trade and revenue effects for the EAC region include studies by [6] [23]. The studies use ex ante approaches in the analysis of welfare effects from the formation of the East African Community customs union, [23] use a partial equilibrium model to estimate trade effects and revenue effects. Their results show that total trade would increase by roughly US \$ 13 million. Trade creation amounts to US \$ 4.5 million and trade diversion to US $\$ 8.7$ million. The biggest trade effects are seen in Tanzania due to its relatively high intra-EAC tariff rates. For all the three countries, trade diversion exceeds trade creation implying that imports are now from high-cost producers, decreasing net welfare. Kenya is found to benefit most from preferential trade liberalization. However this result is expected due to the high export share of Kenyan exports within the EAC. Uganda and Tanzania would gain less from the EAC trade agreement, but their trade balances would not deteriorate significantly. On average, the trade creation figure is quite small and so this would suggest that the total growth in trade accruing to the EAC will be minimal. 
Ref [6] analyses the potential trade impact of the EAC customs union and the extent to which the common external tariff (CET) will liberalize their trade regimes. The study provides simulations to determine the impact of the CET on Kenya. McIntyre uses a static partial equilibrium model using a simulation known as SMART. McIntyre finds that trade creation is the dominant effect of the EAC CET. Preliminary evidence shows that the EAC customs union will have positive trade benefits for Kenya. The EAC CET allows for increased flows of cheaper extra-regional imports that will likely lower consumer prices with positive welfare effects. Overall, the simulation results show an increase in trade of $\$ 193.5$ million with trade creation at \$193.9 million and trade diversion at $\$ 0.3$ million. While these results are larger than those found by [23]; the figures are still small relative to the trade with the rest of the world. This suggests that while the increase in the volume of intra-regional trade is desired, the dynamic effects of regional integration such as improved infrastructure, governance and promotion of investment are of more importance.

Ref [25] provided a detailed analysis of the trade and welfare effects of reciprocity and multilateral liberalization of non-agricultural products on Tanzania and Malawi using a partial equilibrium model, they find that the preferential trade agreement between the EAC and the EU will affect tariff revenue. The tariff revenue was estimated to fall by 54 percent, accompanied by a net welfare loss of Tsh 35,659 million. This suggests that while trade liberalization is desired, negative revenue effects should be expected. [26] in their study on African countries reciprocity trade with the EU shows that trade welfare gains occurred to Malawi of US \$ 2.1 million and Tanzania US $\$ 8.2$ million, suggesting positive revenue effects. In both cases the revenue effects are substantial to affect government budget. In conclusion the studies show that both trade creation and trade diversion effects are expected from Uganda's trade liberalization preferences. However more studies point towards trade creation that trade diversion.

\section{Methodology and Empirical Result}

\subsection{Model Specification and Equations}

The empirical model applied in this analysis is the WITS/SMART partial equilibrium model developed by the World Bank. The model was introduced under the literature review in chapter two along with other trade policy analysis models. The model is employed to estimate trade effects and tariff revenue changes contingent on the specification of alternative trade policy scenarios. The WITS model uses the Armington assumption of product differentiation, it assumes that the source of imports for any given product induce imperfect substitution. The model makes additional assumptions such as trade flow changes do not affect incomes or exchange rates, infinite supply elasticities and iso-elastic import demand functions. These assumptions, although restrictive, are not unreasonable for the case of small open economies.

\subsection{The Partial Equilibrium Model and Data}

The model follows the theoretical formulation by [7] and pioneering work by [21]. The model uses Armington assumption of product differentiation which assumes that the source of imports for any given product encourage imperfect substitution. The partial equilibrium model used in this study is similar to the model used by [1] and [5] who estimates the effect of the EAC customs union on trade, revenue and welfare on EAC partner states. In addition to [1] and [5] work, this study investigates trade and revenue effects under the EAC framework and evaluates alternative trade liberalization scenarios with the DRC and Sudan which are both Uganda's key trade partners. The analysis of the trade diversion, trade creation and tariff revenue effects are driven by the consumer behaviour specified under the model formulation that was adopted by [2].

The import demand function for Uganda is represented by Equation (1), below;

$$
M_{i j k}=F\left(Y_{j}, P_{i j}, P_{i k}\right)
$$

where;

$$
\begin{aligned}
& M=\text { Imports } \\
& Y=\text { National Income } \\
& P=\text { Price } \\
& j=\text { Importing country in this case Uganda } \\
& I=\text { Commodities imported }
\end{aligned}
$$


$k$ = Preference beneficiary country in this case EAC countries, DRC and Sudan. (We consider the period before the new South Sudan and Sudan were born, therefore in this study we consider data for the former Sudan.)

The export supply function of preference beneficiary country is simplified as

$$
X_{i j k}=F\left(P_{i k j}\right)
$$

where $X_{i j k}=$ Exports of commodity $i$ by country $k$ to country $j$.

Exports of preference beneficiary countries and import to Uganda give the standard partial equilibrium equation in (3), which is obtained by equating Equation (1) and (2) to give Equation (3). In this equation we assume exports are equal to imports, if we assume a preferential trade area without taxes, i.e. the domestic price of commodity in the importing country is equal to the price in the exporting country. However this is not always the case since in most cases commodities have an extra portion in form of import taxes plus transport and insurance charges.

$$
M_{i j k}=X_{i j k}
$$

If we assume a preferential trade agreement where taxes are eliminated, the domestic price of commodity $i$ in the importing country $j$ will be equal to the exporting country $k$ 's export price. When taxes are imposed the price will rise by the amount equal to the ad valorem tariff incidence as shown in Equation (4).

$$
P_{i j k}=P_{i k j}\left(1+t_{i j k}\right)
$$

where $t_{i j k}=$ Tariff rate.

\subsection{Trade Creation Effects}

The trade creation effect is defined as the increased demand for the imports from a preference country. In this case the increased demand for the imports of commodity $i$ into Uganda or country $j$ from preference country $k$ in Equation (1). The increased demand for imports is resulting from the price decrease arising from the price changes when tariff are eliminated [2]. Trade creation therefore is comprised of trade expanding aspects of liberalization that lead to the displacement of inefficient producers in the preferential trading area [14]. Following from [15], trade creation formula is derived by totally differentiating the price Equation (4) to get Equation (5).

$$
\mathrm{d} P_{i j k}=P_{i j k} \mathrm{~d} t_{i j k}+\left(1+t_{i j k}\right) \mathrm{d} P_{i j k}
$$

Equations (4) and (5) are then substituted into the elasticity of import demand equation i.e. Equation (5.1) to get Equation (6)

$$
\begin{gathered}
\frac{\Delta M_{i j k}}{M_{i j k}}=\eta_{i}^{m} \frac{\Delta P_{i j k}}{P_{i j k}} \\
\frac{\mathrm{d} M_{i j k}}{M_{i j k}}=\eta_{i}^{m}\left(\frac{\mathrm{d} t_{i j k}}{\left(1+t_{i j k}\right)}+\frac{\mathrm{d} P_{i j k}}{P_{i j k}}\right)
\end{gathered}
$$

where $\eta_{i}^{m}$ is the elasticity of import demand with respect to domestic price, the identity Equation (3) is used to derive the expression for elasticity of export supply Equation (6.1) below

$$
\frac{\mathrm{d} M_{i j k}}{M_{i j k}}=\frac{\mathrm{d} X_{i k j}}{X_{i k j}}
$$

Taking the right hand side of the equation and differentiating it with respect to world prices we get Equation (7)

$$
\frac{\mathrm{d} P_{i k j}}{P_{i k j}}=\frac{1}{\gamma_{i}^{e}} \frac{\mathrm{d} M_{i j k}}{M_{i j k}}
$$

In Equation (7) $\gamma_{i}^{e}$ is the elasticity of import demand for commodity $i$ in the importing country from the relevant trading partner. Substituting Equation (7) into Equation (6) allows the estimation of the trade creation effects to give Equation (8). From Equation (3), Equation (8) is equivalent to exporting country $k$ 's growth of 
exports of commodity $i$ to country $j$

$$
T C_{i j k}=M_{i j k} \eta_{i}^{m} \frac{\mathrm{d} t_{i j k}}{\left(\left(1+t_{i j k}\right)\left(\left(1-\eta_{i}^{m}\right) / \gamma_{i}^{e}\right)\right)}
$$

where $T C_{i j k}=$ Trade creation.

The expression $T C_{i j k}$ represents the sum of trade created over I commodities affected by tariff change. $M_{i j k}$ Represents the current levels of import demand of the given commodity $i$. In this, case trade creation will depend on the current level of imports, the import demand elasticity and the relative tariff change.

Where;

If $\gamma_{i}^{e} \rightarrow \infty$, then Equation (8) can be simplified to give Equation (9):

$$
T C_{i j k}=M_{i j k} \eta_{i}^{m} \frac{\left(1+t_{i j k}^{1}\right)-\left(1+t_{i j k}^{0}\right)}{\left(1+t_{i j k}^{0}\right)}
$$

where $T C_{i j k}$ the sum of trade is created in millions of dollars over $i$ commodities affected by tariff change and $\eta_{i}^{m}$ is the elasticity of import demand for commodity $i$ in the importing country from the trading partner. $M_{i j k}$ is the current level of import demand of the commodity I $t_{i j k}^{0}$ and $t_{i j k}^{1}$ represent tariff rates for commodity $i$ at the initial and end periods respectively. Trade creation then depends on the current level of imports, the import demand elasticity and the relative tariff change. If $T C_{i j k}$ is increasing substantially then there is trade creation.

\subsection{Trade Diversion Effects}

Trade diversion occurs in a preferential trade agreement when efficient producers from outside the preferential trade agreement are displaced by less efficient producers in the preferential trade agreement, [2]. When prices fall in an exporting country, importers purchase more goods from that country and less from countries whose exports are at higher prices. Specifically more efficient suppliers from the rest of the world are displaced by inefficient producers in the preferential trade agreement. In this analysis trade diversion occur when Uganda removes internal tariffs for preferential countries while maintaining tariff on goods from non-preferential country sources. Trade diversion is influenced by the elasticity of substitution which is estimated below.

$$
\sigma_{M}=\frac{\Delta\left(\frac{\sum_{k} M_{i j k}}{\sum_{K} M_{i j K}}\right) /\left(\frac{\sum_{k} M_{i j k}}{\sum_{K} M_{i j K}}\right)}{\Delta\left(\frac{\sum_{k} P_{i j k}}{\sum_{K} P_{i j K}}\right) /\left(\frac{\sum_{k} P_{i j k}}{\sum_{K}^{k} P_{i j K}}\right)}
$$

where $\sigma_{M}$ is the elasticity of substitution with respect to relative prices of the same product from different import sources $k$ denotes imports from one group of exporters, $K$ denotes imports from another group of exporter. The estimation is only across the country group $k$ or $K$ but not across product groups $i$ or across imports of $j$ Equation (10) can be expanded and through substitutions and rearrangements to obtain Equation (11) which is expressed as trade diversion below.

$$
T D_{i j k}=\frac{M_{i j k}}{\sum_{k} M_{i j k}} \frac{\sum_{k} M_{i j k} \sum_{K} M_{i j K} \frac{\Delta\left(P_{i j k} / P_{i j K}\right)}{P_{i j k} / P_{i j K}} \sigma_{M} M_{i j k}+\sum_{K} M_{i j k}+\sum_{k} M_{i j k} \frac{\Delta\left(P_{i j k} / P_{i j K}\right)}{P_{i j k} / P_{i j K}} \sigma_{M}}{\sum_{k}}
$$

where $T D_{i j k}$ are the trade diversion effects.

Equation (11) can be simplified and expressed as Equation (12) to reflect the trade preference, [15] demonstrate the relative price that captures the movement due to changes in tariffs or the ad valorem incidence for the trade preference and the rest of the world (ROW). Therefore, the trade diverted to the EAC can be captured by expressing Equation (11) as Equation (12) 


$$
T D^{\mathrm{RTA}}=\frac{M^{\mathrm{EAC}} M^{\mathrm{ROW}}\left(\frac{1+t_{\mathrm{EAC}}^{1}}{1+t_{\mathrm{EAC}}^{0}}-1\right) \sigma_{M}}{M^{\mathrm{EAC}}+M^{\mathrm{ROW}}+M^{\mathrm{EAC}}\left(\frac{1+t_{\mathrm{EAC}}^{1}}{1+t_{\mathrm{EAC}}^{0}}-1\right) \sigma_{M}}
$$

where

$T D^{\mathrm{RTA}}=$ Trade diversion on commodity $i$ imported from country $k$ into country $j$

$M^{\mathrm{EAC}}=$ Imports from the EAC countries and candidates for EAC membership

$M^{\text {ROW }}=$ Imports from the rest of the world

$\sigma_{M}=$ Substitution elasticity.

$t_{\mathrm{EAC}}^{1} \& t_{\mathrm{EAC}}^{0}=$ are respectively the end and initial periods import tariffs imposed on imports from the preference countries into Uganda with $t_{\mathrm{EAC}}^{1}<t_{\mathrm{EAC}}^{0}$. The higher the value of the elasticity of substitution, the greater will be the trade diversion effects.

\subsection{Total Trade Effect}

The total trade effect is derived by adding Equation (9) and (12) or the trade creation and diversion to give the total trade effect [2].

\subsection{Revenue Effect}

In theory, tariff revenue is given as the product of the tax rate and the value of the commodity as the tax base. In estimating the revenue effects, tariff revenue is calculated for the pre and post implementation period of the preference agreement. In this tariff liberalization process the value of imports is taken as the tax base to which the tax rate is applied to get the tariff revenue. To obtain the revenue effects we obtain the tariff revenue using the tariff rates used before the implementation of the trade agreement and subtract the tariff revenue obtained using tariff rates used after the trade agreement. Thus, the revenue, obtained before the trade agreement is given by the expression below

$$
R_{0}=\sum_{i} \sum_{k} t_{i j k}^{1} P_{i j k} M_{i j k}
$$

After the change in the tariff rate, the new revenue is given by the expression below

$$
R_{1}=\sum_{i} \sum_{k} t_{i j k}^{1} P_{i j k} M_{i j k}
$$

The net revenue as a result of the implementation of the trade agreement would then be the net between $R_{1}$ and $R_{0}$ which is given by the Equation (13) below, the net will either be a positive or negative indicating a revenue increase or loss.

$$
R L=\sum_{i} \sum_{k} \Delta t_{i j k} P_{i j k} M_{i j k}
$$

\section{Alternative Scenarios Considered and Available Data}

Trade agreements, as any type of trade negotiation, contain provisions for gradual phased tariffs reductions. Although phased liberalization processes are usually the norm, the simulations conducted in this study assume the complete and immediate elimination of all import tariffs. This assumption allows the calculation of static effects under the most radical type of liberalization that would reflect long term and perhaps future end scenarios.

The analysis and simulations of the empirical model were carried out for the EAC member as a group and each for the DRC Congo and Sudan. Three alternative possible trade liberalization scenarios were simulated using high and low elasticity values. The analysis was conducted using data available for five different years and averages for those years are presented in the results section. The first scenario considers Uganda completely eliminating existing import tariffs on all four members of the EAC. The second scenario considers Uganda completely eliminating existing import tariffs on DRC imports. DRC is a major trading partner for Uganda, Rwanda, Burundi and Tanzania. The third scenario considers Uganda completely eliminating existing import tariffs on Sudan imports, Sudan is a major trading partner with Uganda and Kenya. 
The empirical model obtains values for trade creation, trade diversion and changes in import duty revenue. The simulations and analysis provide a means of comparing and understanding the implications of alternative policy scenarios for Uganda. The results are very useful for researchers, trade negotiators and policy makers as they discuss the reduction phases in actual trade agreement negotiations.

\section{Data Analysis Technique}

The data utilized in the application is based on the harmonized commodity coding system (HSC) at the six-digit trade level. At this level of aggregation, Uganda has identified $(33,833)$ tariff lines. A calculation at the six-digit level avoids the aggregation of tariff rates and allows for individual tariff line analysis. The information calculations at this level allows for identification of product categories most affected by tariff elimination. The data performed in June 2013.

To examine Uganda's trade creation, trade diversion and revenue effects, we use a SMART/WITS partial equilibrium model. Under the SMART/WITS we first select the country (in this case Uganda) that is going to change its tariff. In the next step we select each year for the tariff and import data to be used in the simulations, the simulation need a starting point in order to interpolate the consequences of the tariff reform. In this simulation we select six separate years 2006 to 2011 for the simulations. Subsequently we select the products involved in the simulation during the tariff reform, the products are those items for which the tariff is changed by the scenario. In this case all products are considered for tariff reform. The above procedure allows in setting up a scenario for simulation. A scenario is made of four sets of parameters as stated below;

1) Partners; These include Burundi, Kenya, Rwanda, Tanzania, Sudan and the DRC.

2) Products; All products are considered in these simulations.

3) Formula; the tax rate considered is zero percent, a Swiss Formula is used in order to reduce tariffs which is defined as $r_{1}=\left(a * r_{1}\right) /\left(a+r_{0}\right)$ with $(a)$ as coefficient to be entered in the parameter box ( $a=16$ is by default in SMART model).

4) Elasticities; these define behaviors and affect the magnitude of the scenario impact.

The import demand elasticity values used in the scenarios are by default in SMART model and have been empirically estimated for each country for every HS 6-digit product. The substitution elasticity value between partners entails a product by product simulation, which is based on the assumption that any product is independent of another product.

The SMART model uses 1.5 as the default import demand elasticity value. The supply elasticity or the export supply elasticity value is by default and SMART uses 99 for an infinite elasticity for all products and partners. The reason is that we are dealing with a single-country simulation tool, so one country is too small to have an impact on the price level of the rest of the world.

The simulation is done year-by-year and it is independent of the amount of products being chosen. The simulation automatically takes place at the 6-digit level. To simulate effects involving other countries cutting their tariffs at the same time, we run several separate simulations of the selected countries i.e. (Burundi, Kenya, Rwanda, Tanzania, Sudan and the DRC are considered).

\section{Simulation Results}

\subsection{Trade Effects}

Trade effects from the simulations of alternative tariff liberalization scenarios are presented under Appendix 1. Tables 1-13 with values for trade creation, trade diversion, revenue and total trade effects relative to total imports are presented under Appendix 1. Equation (9) and (13) allows for the quantification of the trade creation and trade diversion following the elimination of tariff barriers. Estimation of the equations present simulation results for the alternative tariff liberalization scenarios i.e. Uganda and the individual EAC partner states, Uganda and the DRC and lastly Uganda and Sudan.

Table 1 to Table 4 show the first scenario simulating tariff liberalization between Uganda and EAC partner states suggests that trade liberalization with the EAC partner states leads to small but positive trade creation for all EAC member countries with averages of US \$ 898,000. Burundi and Rwanda show higher trade creation effects compared to Kenya and Tanzania. In all the country case there is evidence of small trade diversion, the average trade diversion effect is US \$30,100 for all EAC members. The trade diversion effects are more evident at 
the high elasticity values, compared to the low elasticity values. Trade creation effects are more evident at low elasticity compared to the high elasticity values.

Total trade effects as a percentage of baseline imports, are relatively small in both the low and high elasticities values. Using the low elasticity value total trade effects as a percentage of baseline imports ranged between -0.40 percent and 0.10 percent. Using the high elasticity scenario total trade effects as a percentage of baseline imports ranged from -0.17 percent to 0.86 percent. At both high and low elasticity value Rwanda and Burundi showed the largest total trade effects while Kenya and Tanzania showed the least total trade effects. In terms of trade in monetary value, the total trade values were largest in Kenya while the lowest were in Burundi. Total trade value for the two elasticity values ranged from US \$ 581.9 million to US \$ 1.42 million for the EAC partner states, with an average of US \$928,100 for the period. Overall the results indicate that the trade liberalization between Uganda and EAC partner states could lead to more trade for Uganda.

The trade effects from the second scenario, where liberalization is extended to the DRC, are presented in Table 5. Trade creation effects in the second scenario are more significant compared to the first scenario involving the EAC member states, the average trade creation effects for the DRC is US \$476,300. The average trade diversion effects for the DRC are US \$310,100. The trade diversion average is higher than in the first scenario. In both the low and high elasticity values trade creation effects exceed trade diversion effects, this implies that an Economic Partnership Agreement between Uganda and the DRC would be trade creating.

The DRC scenario shows less trade diversion effects compared to the EAC liberalization scenario, however compares to Sudan the DRC scenario shows more trade diversion effects. The total trade effects as a percentage of baseline imports are still small as in the first scenario. They range from 33 percent to 9.5 percent in low elasticity values, in the high elasticity value the total trade effects as a percentage of baseline imports range from 38 percent to 4.2 percent. The total trade effects as a percentage of total imports are similar to the EAC scenario but they are relatively higher. Hence, compared to EAC countries, the DRC is the most affected by trade diversion. In general on account of higher trade creation effects and higher total trade effects as a percentage of total imports, the results indicate that the trade liberalization between Uganda and DRC could lead to more trade.

The trade effect from the third scenario, where liberalization is extended to the Sudan is presented under Table 6. The results shows trade creation effects for both low and high elasticity values. The average trade creation effects for the Sudan are very small less than US \$ 1000. The trade creation effects are smaller compared to the first and second scenario. The average trade diversion effects for the Sudan are US \$ -5400 which are the least in comparison to the first and second scenario. Scenario three shows the least trade creation and trade diversion effects compared to scenario one and scenario two. In this scenario trade diversion effects are larger than trade creation effect. This is unexpected since Sudan is a major trading partner with Uganda and Kenya. The larger trade diversion effects compared to trade creation effects could be attributed to the limited imports of Sudan goods to Uganda.

In terms of the total trade effects as a percentage of baseline imports, the total trade effects as a percentage of baseline imports are still relatively small under the high and low elasticities. In the case of the low elasticity scenario, the total trade effects as a percentage of baseline imports range from -2.4 percent to -0.30 percent. In the high elasticity scenarios, trade effects as a percentage of total imports range from -5.3 percent to -0.10 percent. In general the results indicate that an EPA between Sudan and Uganda would be trade creating.

\subsection{Revenue Effects}

The removal of import duties from the assortment of international trade taxes could have effects on overall government revenues. Equation (13) allows the quantification of the total change in revenue following the elimination of import duties. Although it is clear that revenues derived from import tariffs could be eliminated in the simulation, the effect on total trade revenue is not clearly defined given that the other trade taxes such as import VAT, Withholding tax, Environmental levy among others are not eliminated. In fact, an increase in the revenues generated by the other trade taxes is possible if trade liberalization leads to significant increases in the value of trade creation. Trade created is subject to levies imposed by the entire array of other international taxes. Therefore revenue effects evaluated in this study focus on the primary effects that result from the loss of import tariff revenue.

The discussion that follows takes into account the average values obtained for the high and low elasticity. The revenue effects from the elimination of tariffs in the first scenario simulating tariff liberalization for the EAC 
partner states are summarized in Table 7 to Table 9. In general, tariff revenue as a percentage of total revenue, amounted to an average of 9 percent from 2006 to 2010. Import duties accounted for an average of 18 percent of international trade revenue for the period 2006 to 2010. Growth in import revenue show decreasing growth trends over the period from 20 percent in 2006 to 17 percent in 2010 and an average decline of 18 percent over the period. However in terms of absolute values the revenue is increasing at a decreasing rate.

\subsection{Patterns of Revenue Effects}

The first scenario involving tariff liberalization with the EAC partner states is presented in Table 7 to Table 10. The table's show Uganda's revenue effects disaggregated for the individual EAC partner states, for the period 2006 to 2010. Table 7 reports that the estimates of revenue effect on Burundi imports to Uganda show negative revenue effects of an average of US \$ 2800 during the period. The negative revenue effects suggest a decrease in imports duty revenue for trade between Uganda and Burundi. On the other hand the results suggest that the trade value between Uganda and Burundi increases from US \$ 170,000 to US \$ 10.8 million during the period, the negative revenue effects are largely attributed to the trade diversion effects.

Table 8 reports that the estimates of revenue effect on Kenya imports to Uganda are positive but small. The average revenue effects are less than US \$ 1000 for the period, which are quite small for the volume of trade between Uganda and Kenya. The positive revenue effects are partly attributed to the increase in trade volume from US \$ 4.08 trillion to US \$ 5.11 trillion during the period. The positive revenue effect is largely attributed to growing trade volume and the net trade creation effects.

Table 9 reports the estimates of revenue effect on Rwanda imports to Uganda, the average revenue effects are positive but small. The revenue effects are less than US \$ 1000, which is similar to Burundi and Kenya. Nonetheless the Rwanda revenue effects are larger than the Burundi and Kenya revenue effects. The growth of Rwanda’s trade volume with Uganda increases from US \$ 4.88 million dollars in 2006 to US \$ 73.89 million dollars in 2010. This could partly explain the larger revenue effects comparison to Burundi and Kenya. Overall positive revenue effects and growth in trade volume suggests possible increases in trade revenue for trade between Uganda and Rwanda.

Table 10 reports the estimates of revenue effect on Tanzania imports to Uganda, the average revenue effects are positive but small. The revenue effects are less than US $\$ 1000$ but similar to the Kenya country case. The import trade values increase from US \$ 289.9 million to US \$ 5652 million during the period. The growth in trade value could suggest an increase in trade taxes. In general the positive revenue effects are largely attributed to growing trade volume and the net trade creation effects.

Overall a large proportion of the negative revenue effects are from Burundi, while a large proportion of positive revenue effects is from Rwanda, Kenya and Tanzania. Uganda's international trade revenue from Burundi decreases while Rwanda, Kenya and Tanzania's international trade revenue to Uganda increase. A large proportion of the increase in revenue effects could be attributed to an increase in trade values between EAC partner's states. The revenue effects from the elimination of tariffs on EAC imports are small but positive for all the countries apart from Burundi which has negative revenue effects. Burundi's negative revenue effects represent tariff revenue losses, while Rwanda, Tanzania and Kenya's positive revenue effects represent revenue increases.

Second scenario involving tariff liberalization with the DRC

The second scenario considers the revenue effects that result from the elimination of duties on imports from DRC, the results are presented in Table 11. The average revenue effects are negative with an average of US $\$ 45,966$. The negative revenue effects suggest decreases in import duties for a probable trade agreement between Uganda and DRC. The trade values increase from US \$ 0.39 million in 2006 to US \$ 25.90 million in 2010, suggesting that a probable trade agreement between Uganda and DRC will lead to growth in trade volumes.

Trade liberalization in this scenario, which includes tariff elimination on goods coming from the DRC, has the largest negative revenue effects. This scenario shows that an EPA between Uganda and DRC would lead to decline in trade revenue, however considering the small revenue effects, one could conclude that the negative revenue effects don't warrant any alarm. Therefore it's more likely that an EPA between Uganda and DRC would lead to an increase in trade volumes which would facilitate in abating the negative revenue effects.

Third scenario involving tariff liberalization with Sudan

The third scenario considers the revenue effects that result from the elimination of duties on imports from 
Sudan are presented in Table 12. The revenue effects are small but positive with an average of less than US $\$ 1000$. The trade values increase from US \$ 40,000 in 2006 to US \$ 31.5 million in 2010. The positive revenue effects are attributed to the increase in trade volume between Uganda and Sudan. Table 12 reports an increase in trade volume from a probable trade agreement between Uganda and Sudan. The revenue effects are bigger than DRC, Rwanda and Burundi cases, suggesting that a trade agreement between Sudan would increase Uganda's trade. Overall trade liberalization in this scenario has positive revenue effects. The positive revenue effects suggest that an EPA between Uganda and Sudan would lead to an increase in tariff revenue for Uganda.

\subsection{Imports Most Affected by Trade and Revenue Effect}

Using the WITS model with highly disaggregated six-digit level import data, permits the identification of products that have the largest trade and revenue effects. This information is useful to researcher, policymakers and trade negotiators when in the process of negotiating trade liberalization agreements, especially in the context of special and differential treatment. Table 13 in Appendix 1 presents the five most affected products for each individual country under the three different liberalization scenarios. Due to the similarity in results obtained for the low and high elasticity values for the different years, only the low elasticity scenario for year 2010 is presented. The sensitive products are sorted and ranked by trade effects as well as by revenue effects.

The first scenario considers the top five most affected products for each individual EAC partner states. These were sorted and ranked by trade and revenue effects (see Table 13). Burundi liberalization analysis shows that the top five most affected products with the highest trade and revenue effects to Uganda comprised of milk and cream in solid form, coffee, not roasted or decaffeinated, iodine, mineral or chemicals with fertilizer, cotton mot carded or combed and worn clothing. The products most affected by tariff liberalization in terms of largest trade and revenue effect for Burundi are primarily products that are produced in Uganda. This suggests that the above products could be selected for special and differential treatment to protect the domestic producers under the advents of liberalization.

The analysis involving Kenya shows that the top five most affected products with the highest trade and revenue effects to Uganda comprised of Portland cement, salt/pure sodium chloride, coils of iron, un-denatured ethyl alcohol, and medicaments of mixed and unmixed products. The products most affected by tariff liberalization in terms of largest trade and revenue effect from Kenya are primarily products where Uganda has limited domestic production. This suggests that the above products could be selected for reduced tariff in order to supplement the limited domestic production. This could improve the welfare of consumers.

The scenario involving Rwanda shows that the top five most affected products with the highest trade and revenue effects to Uganda comprised of electricity, vacuum flasks, road tractors for semi-trailer, wheat not for agricultural sowing, house hold and toilet articles. The products most affected by tariff liberalization in terms of largest trade and revenue effect for Rwanda are primarily products where Uganda has limited domestic production. This suggests that the above products could be selected for reduced tariff in order to supplement the limited domestic production this could improve consumer welfare.

The analysis involving Tanzania shows that the top five most affected products with the highest trade and revenue effects to Uganda comprised of light oil preparations, knitted and orchestrated bed spreads, carboys bottles, flasks, stoppers, lid and others, motor spirits and transformers. The products most affected by tariff liberalization in terms of largest revenue effect from Tanzania are primarily products where Uganda has limited domestic production. This suggests that the above products could be selected for reduced tariff in order to supplement the limited domestic production. This will increase consumer welfare, however some of these products have domestic production and these could call for preferential tariff treatment of the domestic producers.

The scenario involving DRC shows that the top five most affected products with the highest trade and revenue effects to Uganda comprised of beauty make up preparations, wood sawn and chipped, specified tropical woods, vanilla, wood sawn and chipped clockwise and motorcycles. The products most affected by tariff liberalization in terms of largest trade and revenue effect from DRC are primarily products where Uganda has limited domestic production. This suggest that the above products could be selected for reduced tariff in order to provide for the limited domestic production which will increase welfare for consumers, however some of these products have domestic production and such products could call for preferential tariff treatment.

The scenario involving Sudan shows that the top five most affected products with the highest trade and revenue effects to Uganda comprised of light oil preparations, knitted and orchestrated bed spreads, carboys bottles, 
flasks, stoppers, lid and others, motor spirits and transformers. The products most affected by tariff liberalization in terms of largest revenue effect from Sudan are primarily products where Uganda has limited domestic production. This could suggest that the above products could be selected for reduced tariff in order to provide for the limited domestic production which will increase welfare for consumers. However compared to other country cases Sudan shows the products with the least domestic production.

Overall the country analysis of imports most affected by largest trade effects and revenue effects show that the commodities from Burundi and Rwanda are domestically produced in Uganda. This could call for preferential treatment focussing on protecting local producers. Commodities from Kenya and Tanzania are products with limited domestic production in Uganda, this could call for reduced tariff rate to improve domestic consumption of these products. The products most affected by revenue and trade effects in scenarios involving DRC and Sudan suggest that Uganda's domestic producers could benefit, since the products are not produced in Uganda.

\subsection{Conclusion}

The chapter has applied a partial equilibrium model to estimate the likely trade and revenue effects on Uganda under EAC. The chapter also estimates trade and revenue effects for the DRC and Sudan. The trade liberalization scenarios simulated provide insight into the effects of tariff elimination, although it is clear that simulations performed were limited to the removal of import duties while a broad array of other border charges remained, results are nevertheless noteworthy.

The EAC trade liberalization scenario leads to trade creation effects. Among the EAC partner states, Rwanda has the largest trade creation effects. DRC has larger trade creation effects compared to Sudan. Small trade diversion effects are evident among the EAC partner states, Burundi has the largest trade diversion effects among EAC partner states and between Sudan and DRC, and the DRC has the largest trade diversion effects. The analysis on DRC and Sudan suggests that trade agreements between Uganda and the two countries would increase Uganda's trade and revenue. Tariff revenue effects in all scenarios simulated were small, the revenue implications of removal of applied rates depend on the price elasticity of imports. High elasticity shows larger trade and revenue effects compared to low elasticity.

It is identified that products most affected by largest trade creation effects are primarily products that are not produced on the local market. However, there are a few items that could be produced locally. One could propose that these products should be earmarked for preferential tariff treatment. Such products include garments of other textiles, knitted or crocheted, polythene or polypropylene, breeches of other textiles, t-shirts, singlet's knitted or crocheted, sacks and bags, used for packing goods, of other textiles and some other foods among agricultural and raw materials. The commodities could be included on the sensitive list and charged a higher tariff rate as a way of protecting local producers.

The products with largest revenue effects include worked monumental or building stone, woven fabrics of synthetic filament yarn, flat-rolled products of iron or non-alloy steel, textiles; wearing apparel and dressing and rubber and plastic products. Tariffs on these products could be reduced or completely removed to enable growth in the construction industry.

The results obtained in this study are similar to results by [15] and [5]. Both Studies use a SMART-WITS partial equilibrium model to estimate the effect of the EAC customs union on trade and revenue effects on Uganda. The studies quantify revenue effects, trade creation and trade diversion effects. The study determines that contrary to the fears expressed by Uganda that it will totally lose out on trade are not accurate. They show evidence of more trade creation than diversion, leading to positive net trade effect. They demonstrate that whereas some sectors are likely to be impacted negatively, others would be impacted positively. The shortcoming of these studies is that they are based on Uganda and EAC, yet DRC and Sudan Uganda's key trading partners are not considered. The results from these studies are similar to findings in this study that show evidence of more trade creation than diversion, leading to positive trade effect.

The study's major conclusions are that Uganda is likely to record trade creations effects, small trade diversion effects and small positive revenue effects over the existing levels. However the trade values are bound to increase significantly over the existing levels.

\subsection{Policy Implications}

The elimination of import duties in the EAC could lead to an increase in trade and revenue. The identification of 
products most affected by tariff revenue cuts, or products that have the largest trade and revenue effects, can be very useful in setting timetables and liberalization phases, however, beyond usefulness in many settings, the analysis performed can be viewed in the broader issue of trade liberalization as policy direction.

The findings provide empirical support in assessing the more appropriate courses of action for Uganda under the EAC trade agreement. In light of the findings, the more appropriate courses of action for Uganda would be to advocate for the inclusion of DRC and Sudan under the EAC trade agreement, or Uganda entering economic partnership agreement with both Sudan and DRC.

These results coincide with the broader theoretical arguments and policy suggestions made by [27]. The above studies suggest that trade liberalization is likely to lead to more trade creation for small countries that are trading among each other than trading under the multilateral trading system. The implications derived from this research, provide empirical support to theoretical arguments that are consistent with the notion that small countries like the EAC partner states would be better served by trading with each other.

\section{Acknowledgements}

I would also like to express my gratitude to Associate Professor Eria Hisali and Dr. Edward Bbale for the very helpful comments and constructive suggestions on econometric analysis.

\section{References}

[1] Othieno, L. and Shinyekwa, I. (2011) Trade, Revenue and Welfare Effects of the East African Community Customs Union Principle of Asymmetry on Uganda: An Application of Wits-Smart Simulation Model. Research Series 150480, Economic Policy Research Centre (EPRC), Kampala.

[2] Laird, S. and Yeats, A. (1986) The UNCTAD Trade Policy Simulation Model: A Note on the Methodology, Data and Uses, UNCTAD Discussion Paper No. 19, Geneva.

[3] Mugisha, E., Onyango, C.H. and Mugoya, P. (2009) An Evaluation of the Implementation and Impact of the East African Community Customs Union. EAC Secretariat, Arusha.

[4] Nielsen, L. and Zouhon-Bi, S.G. (2007) ECOWAS-Fiscal Revenue Implications of the Prospective Economic Partnership Agreement with the EU. Africa Region Working Paper Series Number 103, World Bank, Washington DC.

[5] Khorana, S., Kimbugwe, K. and Perdikis, N. (2009) Assessing the Welfare Effects of the East African Community Customs Union's Transition Arrangement on Uganda. Journal of Economic Integration, 24, 685-708. http://dx.doi.org/10.11130/jei.2009.24.4.685

[6] McIntyre, M. (2005) Trade Integration in EAC: An Assessment for Kenya. IMF Working Paper No. 05 (143), Washington DC.

[7] Viner, J. (1950) The Customs Union Issue. Carnegie Endowment for International Peace, New York.

[8] Meade, J.E. (1955) The Theory of Customs Unions. North-Holland, Amsterdam.

[9] Panagariya, A. (1997) The Meade Model of Preferential Trading: History, Analytics, and Policy Implications. In: Cohen, B., Ed., International Trade and Finance: New Frontiers for Research, Essays in Honour of Peter B. Kenen, Cambridge University Press, New York, 57-88. http://dx.doi.org/10.1017/CBO9780511528392.004

[10] Lipsey, R.G. (1960) The Theory of Customs Unions: A General Survey. Economic Journal, 70, 496-513. http://dx.doi.org/10.2307/2228805

[11] Lipsey, R.G. (1957) The Theory of Customs Unions: Trade Diversion and Welfare. Economica, 24, 40-46. http://dx.doi.org/10.2307/2551626

[12] Johnson, H.G. (1960) The Economic Theory of Customs Union. Pakistan Economic Journal, 10, 14-32.

[13] Cooper, C.A. and Massell, B.F. (1965) Toward a General Theory of Customs Unions for Developing Countries. The Journal of Political Economy, 73, 461-476.

[14] Mundell, R.A. (1964) Tariff Preferences and the Terms of Trade. The Manchester School, 32, 1-13. http://dx.doi.org/10.1111/j.1467-9957.1964.tb01029.x

[15] Corden, W.M. (1966) The Structure of a Tariff System and the Effective Protective Rate. Journal of Political Economy, 74, 221-237. See Effective Rate of Protection. Cowen, Glazer and McMillan, 1994.

[16] Busse, M. and Großmann, H. (2004) Assessing the Impact of ACP/EU Economic Partnership Agreement on West African Countries. HWWA Discussion Papers 294, Hamburg Institute of International Economics (HWWA), Hamburg.

[17] Tinbergen, J. (1962) Shaping the World Economy: Suggestions for an International Economic Policy. The Twentieth Century Fund, New York. 
[18] Li, X. (2004) Trade Liberalization and Real Exchange Rate Movement. IMF Staff Papers 51, Washington DC, 553-584.

[19] Piermartini, R. and Teh, R. (2005) Demystifying Modelling Methods for Trade Policy. Discussion Paper no. 10, World Trade Organization, Geneva.

[20] Cernat, L. (2001) Assessing Regional Trade Arrangements: Are South-South RTA’s More Trade Diverting? International Trade 0109001, EconWPA, Munich.

[21] Verdoorn, P.J. (1960) The Intra-Block Trade of Benelux. In: Robinson, E.A.G., Ed., Economic Consequences of the Size of Nations, Macmillan \& Co., London, 291-332.

[22] Karemera, D. and Koo, W. (1994) Trade Creation and Diversion Effects of the U.S.-Canadian Free Trade Agreement. Contemporary Economic Policy, 12, 12-23. http://dx.doi.org/10.1111/j.1465-7287.1994.tb00408.x

[23] Busse, M. and Shams, R. (2003) Trade Effects of the East African Community: Do We Need a Transitional Fund? Hamburgische Welt-Wirtschafts-Archiv (HWWA) Discussion Paper 240, Hamburg.

[24] Busse, M., Matthias, H. and Koopmann, G. (2000) Preferential Trade Agreements: The Case of EU-Mexico. HWWA Discussion Papers 103, Hamburg Institute of International Economics (HWWA), Hamburg.

[25] Zgovu, E., Milner, C. and Morrissey, O. (2007) Adjusting to Bilateral Trade Liberalisation under an EPA: Evidence for Mauritius. University of Nottingham, Nottingham.

[26] Karingi, S., Lang, R., Oulmane, N., Perez Jallab, M.S. and Hammouda, H.B. (2005) Economic and Welfare Impacts of the EU-Africa Economic Partnership Agreements. ATCP Work in Progress No. 10, Addis Ababa.

[27] Grunbum, M. (2007) Trade and Tariff Revenue Effects for the Organization of Eastern Caribbean. University of Florida, Gainesville. 


\section{Appendix 1. Trade and Revenue Effects}

\section{Trade Effects}

Table 1. Burundi.

\begin{tabular}{cccccc}
\hline \multicolumn{5}{c}{ 0 percent Rate } \\
\hline Years & $\begin{array}{c}\text { Trade Value in } 1000 \\
\text { USD }\end{array}$ & $\begin{array}{c}\text { Trade Creation Effect } \\
\text { in 1000 USD }\end{array}$ & $\begin{array}{c}\text { Trade Diversion Effect } \\
\text { in 1000 USD }\end{array}$ & $\begin{array}{c}\text { Trade Total Effect } \\
\text { in 1000 USD }\end{array}$ & $\begin{array}{c}\text { Trade Effects Relative } \\
\text { to Total Imports }\end{array}$ \\
\hline 2010 & 83.36 & 0.00 & 0.00 & 0.00 & 0.00 \\
2009 & 660.74 & 0.00 & 0.00 & 0.00 & 0.00 \\
2008 & 660.74 & 0.00 & 0.00 & 0.00 & 0.00 \\
2007 & 459.08 & 0.01 & 0.12 & 0.22 & -0.00 \\
2006 & 11.39 & -1.08 & -2.55 & -6.05 & 0.00 \\
\hline
\end{tabular}

Table 2. Kenya.

\begin{tabular}{|c|c|c|c|c|c|}
\hline \multicolumn{6}{|c|}{0 percent Rate } \\
\hline Years & $\begin{array}{l}\text { Trade Value in } 1000 \\
\text { USD }\end{array}$ & $\begin{array}{l}\text { Trade Creation Effect } \\
\text { in } 1000 \text { USD }\end{array}$ & $\begin{array}{l}\text { Trade Diversion Effect } \\
\text { in } 1000 \text { USD }\end{array}$ & $\begin{array}{l}\text { Trade Total Effect } \\
\text { in } 1000 \text { USD }\end{array}$ & $\begin{array}{l}\text { Trade Effects Relative } \\
\text { to Total Imports }\end{array}$ \\
\hline 2010 & 456967.3 & 0.00 & -187.17 & -312.0 & 0.00 \\
\hline 2009 & 123424.6 & 0.00 & -3.35 & -5.6 & 0.00 \\
\hline 2008 & 138207.7 & 25.04 & 60.56 & 142.7 & 0.00 \\
\hline 2007 & 121215.2 & 207.2 & 325.8 & 888.3 & 0.01 \\
\hline 2006 & 105304.8 & -9825.9 & -11559.7 & -35642.6 & -0.34 \\
\hline \multirow[t]{2}{*}{2005} & 102444.3 & 143.6 & 175.2 & 531.3 & 0.01 \\
\hline & 148,121 & -1181.3 & $-1,399$ & -4299.8 & -0.04 \\
\hline
\end{tabular}

Table 3. Rwanda.

\begin{tabular}{|c|c|c|c|c|c|}
\hline \multicolumn{6}{|c|}{0 percent Rate } \\
\hline Year & $\begin{array}{c}\text { Trade Value in } 1000 \\
\text { USD }\end{array}$ & $\begin{array}{l}\text { Trade Creation Effect } \\
\text { in } 1000 \text { USD }\end{array}$ & $\begin{array}{c}\text { Trade Diversion Effect } \\
\text { in } 1000 \text { USD }\end{array}$ & $\begin{array}{l}\text { Trade Total Effect } \\
\text { in } 1000 \text { USD }\end{array}$ & $\begin{array}{l}\text { Trade Effects Relative } \\
\text { to Total Imports }\end{array}$ \\
\hline 2010 & 356.02 & 0.00 & -0.35 & -0.58 & 0.00 \\
\hline 2009 & 1046.13 & 0.00 & -0.02 & -0.03 & 0.00 \\
\hline 2008 & 1046.13 & 0.00 & -0.02 & -0.03 & 0.00 \\
\hline 2007 & 888.07 & 3.15 & 7.02 & 16.95 & 0.02 \\
\hline 2006 & 258.65 & -11.01 & -22.73 & -56.23 & -0.22 \\
\hline \multirow[t]{2}{*}{2005} & 355.33 & 10.31 & 20.59 & 51.50 & 0.14 \\
\hline & 1119.85 & 0.31 & 0.56 & 1.45 & -0.01 \\
\hline
\end{tabular}


Table 4. Tanzania.

\begin{tabular}{rccccc}
\hline Year & $\begin{array}{c}\text { Trade Value in } 1000 \\
\text { USD }\end{array}$ & $\begin{array}{c}\text { Trade Creation Effect } \\
\text { in 1000 USD }\end{array}$ & $\begin{array}{c}\text { Trade Diversion Effect } \\
\text { in 1000 USD }\end{array}$ & $\begin{array}{c}\text { Trade Total Effect } \\
\text { in 1000 USD }\end{array}$ & $\begin{array}{c}\text { Trade Effects Relative } \\
\text { to Total Imports }\end{array}$ \\
\hline 2010 & 53420.4 & 0.0 & -9.7 & -16.1 & 0.00 \\
2009 & 12691.8 & 0.0 & -0.5 & -0.8 & 0.00 \\
2008 & 12691.8 & 0.0 & -0.5 & -0.8 & 0.00 \\
2007 & 8244.7 & 0.0 & -10.0 & -16.7 & 0.00 \\
2006 & 14425.4 & -862.2 & -915.3 & -2962.4 & -0.21 \\
2005 & 12188.2 & 0.0 & -2.0 & -3.3 & 0.00 \\
& 17280.2 & -107.8 & -117.3 & -375.1 & -0.03 \\
\hline
\end{tabular}

Table 5. DRC.

\begin{tabular}{rccccc}
\hline \multicolumn{7}{c}{ Y percent Rate } \\
\hline Year & $\begin{array}{c}\text { Trade Value in } 1000 \\
\text { USD }\end{array}$ & $\begin{array}{c}\text { Trade Creation Effect } \\
\text { in 1000 USD }\end{array}$ & $\begin{array}{c}\text { Trade Diversion Effect } \\
\text { in 1000 USD }\end{array}$ & $\begin{array}{c}\text { Trade Total Effect } \\
\text { in 1000 USD }\end{array}$ & $\begin{array}{c}\text { Trade Effects Relative } \\
\text { to Total Imports }\end{array}$ \\
\hline 2010 & 1190.92 & 62.57 & 1447.78 & 2517.25 & 2.11 \\
2009 & 300.11 & 25.01 & 64.32 & 148.88 & 0.50 \\
2008 & 300.11 & 25.01 & 64.32 & 148.88 & 0.50 \\
2007 & 28.80 & 1.32 & 3.44 & 7.94 & 0.28 \\
2006 & 18.23 & -1.36 & -3.92 & -8.80 & -0.48 \\
2005 & 40.60 & 0.77 & 1.74 & 4.19 & 0.10 \\
\end{tabular}

Table 6. Sudan.

\begin{tabular}{|c|c|c|c|c|c|}
\hline \multicolumn{6}{|c|}{0 percent Rate } \\
\hline Year & $\begin{array}{l}\text { Trade Value in } 1000 \\
\text { USD }\end{array}$ & $\begin{array}{l}\text { Trade Creation Effect } \\
\text { in } 1000 \text { USD }\end{array}$ & $\begin{array}{c}\text { Trade Diversion Effect } \\
\text { in } 1000 \text { USD }\end{array}$ & $\begin{array}{l}\text { Trade Total Effect } \\
\text { in } 1000 \text { USD }\end{array}$ & $\begin{array}{l}\text { Trade Effects Relative } \\
\text { to Total Imports }\end{array}$ \\
\hline 2010 & 116.67 & 0.00 & -0.03 & -0.05 & 0.00 \\
\hline 2009 & 83.96 & 0.00 & 0.00 & -0.01 & 0.00 \\
\hline 2008 & 83.96 & 0.00 & 0.00 & -0.01 & 0.00 \\
\hline 2007 & 162.28 & 0.00 & 0.00 & 0.00 & 0.00 \\
\hline 2006 & 3.47 & 0.00 & 0.01 & 0.02 & 0.01 \\
\hline \multirow[t]{2}{*}{2005} & 176.24 & 0.00 & -0.01 & -0.02 & 0.00 \\
\hline & 3760.84 & 0.00 & -0.04 & -0.07 & 0.006 \\
\hline
\end{tabular}

\section{Revenue Effects}

Table 7. Burundi.

\begin{tabular}{ccc}
\hline Years & Trade Value in 1000 USD & Revenue Effect in 1000 USD \\
\hline 2010 & 10,870 & 0.00 \\
2009 & 4260 & 0.00 \\
2008 & 9090 & -12.50 \\
2007 & 7870 & -02.00 \\
2006 & 170 & -1.30 \\
\hline
\end{tabular}


Table 8. Kenya.

\begin{tabular}{ccc}
\hline Years & Trade Value in 1000 USD & Revenue Effect in 1000 USD \\
\hline 2010 & $5,115,310$ & 0.00 \\
2009 & $5,026,590$ & 0.00 \\
2008 & $5,113,340$ & 0.00 \\
2007 & $4,956,870$ & 0.00 \\
2006 & $4,080,150$ & 0.00 \\
\hline
\end{tabular}

Table 9. Rwanda.

\begin{tabular}{ccc}
\hline Years & Trade Value in 1000 USD & Revenue Effect in 1000 USD \\
\hline 2010 & 73,890 & 0.1 \\
2009 & 30,710 & 0.00 \\
2008 & 28,790 & 0.00 \\
2007 & 37,860 & 0.20 \\
2006 & 4880 & 0.00 \\
\hline
\end{tabular}

Table 10. Tanzania.

\begin{tabular}{ccc}
\hline Years & Trade Value in 1000 USD & Revenue Effect in 1000 USD \\
\hline 2010 & $5,652,800$ & 0.00 \\
2009 & 407,980 & 0.00 \\
2008 & 554,830 & 0.00 \\
2007 & 308,000 & 0.00 \\
2006 & 289,950 & 0.00 \\
\hline
\end{tabular}

Table 11. DRC.

\begin{tabular}{ccc}
\hline Years & Trade Value in 1000 USD & Revenue Effect in 1000 USD \\
\hline 2010 & 25,900 & -138.76 \\
2009 & 8980 & -62.76 \\
2008 & 3220 & -130.73 \\
2007 & 410 & 35.36 \\
2006 & 390 & 67.06 \\
\hline
\end{tabular}

Table 12. Sudan.

\begin{tabular}{ccc}
\hline Years & Trade Value in 1000 USD & Revenue Effect in 1000 USD \\
\hline 2010 & 31,560 & 0.00 \\
2009 & 2570 & 0.00 \\
2008 & 960 & 0.00 \\
2007 & 1740 & 0.00 \\
2006 & 40 & 0.00 \\
\hline
\end{tabular}




\section{Products with Largest Trade and Revenue Effects}

Table 13. The five most products affected by the largest upper case trade and Revenue effects for the EAC, DRC and Sudan.

\begin{tabular}{|c|c|c|}
\hline & HSC Code & Imports Most Affected by Trade Effects \\
\hline & & BURUNDI \\
\hline 1 & 40210 & Milk and cream in solid form \\
\hline 2 & 90111 & Coffee not roasted or decaffeinated \\
\hline 3 & 281121 & Iodine \\
\hline 4 & 310520 & Mineral or chemical fertilizers with nitrogen \\
\hline \multirow[t]{2}{*}{5} & 520100 & Cotton not carded or combed \\
\hline & & KENYA \\
\hline 1 & 252329 & Portland cement \\
\hline 2 & 250100 & Salt/pure sodium chloride \\
\hline 3 & 720918 & Coils of iron \\
\hline 4 & 220710 & Un-denatured ethyl alcohol \\
\hline \multirow[t]{2}{*}{5} & 300490 & Medicaments of mixed and unmixed products \\
\hline & & RWANDA \\
\hline 1 & 271600 & Electricity \\
\hline 2 & 961700 & Vacuum flasks \\
\hline 3 & 870120 & Road tractors for semi-trailer \\
\hline 4 & 100190 & Wheat not for agricultural sewing \\
\hline \multirow[t]{2}{*}{5} & 392490 & House hold and toilet articles \\
\hline & & TANZANIA \\
\hline 1 & 271019 & Light oil preparations \\
\hline 2 & 630491 & Knitted and orchestrated bed spreads \\
\hline 3 & 701090 & Carboys bottles, flasks, stoppers, lid and others \\
\hline 4 & 271011 & Motor spirits \\
\hline \multirow[t]{2}{*}{5} & 850433 & Transformers \\
\hline & & DRC \\
\hline 1 & 330499 & Beauty make up preparations \\
\hline 2 & 440729 & Wood sawn and chipped \\
\hline 3 & 440721 & Specified tropical woods \\
\hline 4 & 90500 & Vanilla \\
\hline 5 & 440799 & Wood sawn and chipped clockwise \\
\hline \multirow[t]{2}{*}{6} & 871120 & Motorcycles \\
\hline & & SUDAN \\
\hline 1 & 890590 & Light vessels, fire floats and floating cranes \\
\hline 2 & 120430 & Waste and scrap of iron and steel \\
\hline 3 & 841182 & Gas turbine \\
\hline 4 & 720410 & Waste and scrap of cast iron \\
\hline 5 & 842959 & Self-propelled bull dozers and excavators \\
\hline
\end{tabular}

